\title{
TRADISI MENULIS ILMUAN MUSLIM NUSANTARA SEJAK ZAMAN KERAJAAN HINGGA MASA KONTEMPORER
}

\author{
Zailani* \\ Universitas Muhammadiyah Sumatera Utara \\ *Email: zailani@umsu.ac.id
}

\begin{abstract}
The title of this paper is "The Writing Tradition of Muslim Scientists in the Archipelago Since The Age of Kingdom to Contemporary Period." How significant is the development of the writing tradition among the scientist in the age of kingdom. What are the things that encourage these scientists to perform the writing activities. Then materially, which subject fields that muslim scientist are interested in. And also in the contemporary era, this is which is discussed in this paper. This paper is intended to discover the uniqueness of scientist in each age. It is also expected to explore whether or not there are similarities and differences between different times. This paper is qualitative type with the library research approach. By studying the history books of the Islamic empires in the Archipelago and the writings related to the work of Muslim scientists. This paper is the way how the present generation and also the future generation to be able to track and respect bistory, by studying and preserving it.
\end{abstract}

Key words: Writing, Muslim scientists and Archipelago.

\begin{abstract}
ABSTRAK
Judul tulisan ini adalah "Tradisi Menulis Ilmuan Muslim Nusantara Sejak. Zaman Kerajaan Hingga Masa Kontemporer". Sudah sampai sejauh mana perkembangan tradisi menulis pada masa Kerajaan. Hal-bal apa saja yang mendorong para ilmuan tersebut untuk melakukan aktivitas di atas. Kemudian secara materi, bidang-bidang apa saja yang diminati oleh ilmuan muslim Nusantara. Begitu juga pada masa zaman kontemporer, Ini salah satu bagian yang dikaji. Berupaya menemukan kekhasan masing -masing zaman. Juga dibarapkan mampu mencari apakah ada atau tidak. kesamaan dan perbedaan di antara masa yang berbeda. Tulisan ini berjenis kualitatif, dengan pendekatan library research. Dengan mengkaji buku sejarah kerajaan Islam di Nusantara dan tulisan yang berbubungan dengan karya para ilmuan ilmuan muslim. Tulisan ini merupakan salah satu cara upaya generasi sekarang dan akan datang untuke. dapat melacak dan menghormati sejarah, dengan mempelajari dan melestarikannya.
\end{abstract}

Key words:Menulis, Ilmuan Muslim dan Nusantara 


\section{PENDAHULUAN}

Menulis adalah salah satu cara orang untuk menyampaikan ide-ide pemikiran. Ketokohan seseorang dapat dilihat bukan hanya disaat dia berbicara tapi juga disaat menulis. Bahkan manfaat menulis jauh lebih baik dibandingkan hanya memakai kebiasaan orasi. Kelebihan menulis bukan hanya dapat dibaca oleh orang yang hidup sezaman dengan penulis, tapi juga pasca kematian penulis, karya-karya dan ide-ide sang tokoh dapat dikenali dengan membaca hasil karya tangannya.

Seorang cendekiawan dengan mudah menyampaikan apa yang dipikiran dengan lebih lama melalui tulisan. Bahkan untuk mengajak dan mendorong orang lain untuk melakukan sesuatu yang diinginkan tanpa harus bertemu bersentuhan. Maka media yang paling efektif adalah dengan goresan tangan. Dalam konteks sejarah, tulisanlah yang dapat menjelaskan apa yang terjadi pada masa itu. Sekalipun ada peninggalanpeninggalan sebagai hasi karya peradaban, namun gambaran penjelasan apa yang terjadi akan lebih terang dengan tulisan. Sama halnya dengan dengan cendekiawan muslim di Indonesia, untuk mengenal kepribadian penulis bisa dengan membaca buku-bukunya.

$$
\text { Dalam makalah ini akan }
$$

dibahas tradisi menuliscendekiawa muslim Indonesia, baik pada zaman kerajaan Islam atau pada abad 20. Bagaimana tradisi ini menjadi bagian yang sepantasnya diapreasi oleh semua orang. Karena secara kuantitatif dan kualitatif setting sosial turut mempengaruhi bagaimana tradisi tulis-menulis terus terjaga pada cendekiawan muslim Indonesia. Masa suram saat terjajah, peperangan serta kebijakan politik menjadi bagian yang tidak terbantahkan dalam melihat perkembangan budaya menulis pada cendekiawan muslim di Indonesia. Terkhusus pada pemerintah, ini perlu untuk dikaji karena dengan cara ini para pembaca dan ahli sejarah akan dapat mengetahui kebiasaan ilmiah para inteletual muslim pada masa lalu dan juga menjadi evaluasi dari sistem kebijakan sebagai upaya meningkatkan karya-karya ilmiah dari ilmuan. Terkhusus cendekiawan muslim, munculnya generasi berkualitas dengan ditopang oleh regulasi dan peraturan seperti penghargaan dapat menjaga konsitensi para penulis dalam tradisi tersebut.

\section{HASIL DAN PEMBAHASAN}

A. Akar Doktrinal Tradisi Menulis dalam Islam

Islam sebagai agama, membawa pesan yang bisa bersifat larangan dan perintah atau dalam bentuk yang lain. Ini dapat dilihat dengan kandungan Al-Qur'an, betapa Al-Qur'an mengandung segalagalanya (Harun, 2008: 25). Salah satu pesan yang sakral adalah perintah menulis. Pemakalah merenung, AlQur'an diturunkan dengan membawa perintah menulis, tapi wahyu yang diturunkan tersebut kepada Seorang 
nabi yang tidak bisa membaca dan menulis. Namun disinilah letak skenario Allah. Secara historis, muncul orang-orang yang meragukan keabsahan Al-Qur'an dengan menuding bahwa Al-Qur'an buatan Muhammad. Argumentasi itu terbantahkan, baik saatRasul masih hidup atau setelah beliau wafat. Bagaimana mungkin seorang yang yang tidak bisa membaca dan menulis mampu menulis ayat yang begitu agung.

Kemudian dalam konteks tauhid bahwa segala sesuatu yang dikerjakan atas niat karena Allah itu adalah ibadah (Shihab, 2007:305307). Bagi seorang cendekiawan muslim tentu sangat memahami apa yang dikerjakan, tidaklah sia-sia. Menulis bagi mereka adalah salah satu cara beribadah kepada Allah dan menjadi bagian amalan sholeh. Kekuatan doktrin amalan sholeh dan ibadah merupakan kekuatan mental dan spirit yang tak terbantahkan dalam memberikan motivasi kepada para cendekiawan untuk menulis. Karakter inilah yang mejadi salah satu faktor karya mereka tetap abadi sekalipun mereka tidak pernah bertemu kepada para pembaca karyakarya mereka. Selain itu menulis bukan saja upaya menyampaikan gagasan tapi juga untuk mengkekalkan ilmu yang dimiliki. Karena sesungguhnya ilmu yang dituangkan kembali dalam tulisan akan memberikan daya ingat yang lebih baik. Kemudian tulisan merupakan salah satu cara dalam menyimpan apa yang sudah diketahui. Karena manusia mempunyai sifat lupa (Shihab, 2006: 294) dan keliru dalam mengingat sesuatu maka menuliskan kembali merupakan upaya akademik yang sangat penting untuk dikerjakan.

$$
\text { Al-Qur'an sebagai kitab }
$$

wahyu, diturunkan diawali dengan surah al-'Alaq,(Shihab, 2006: 439). Salah satu isinya perintah membaca.Sejalan dengan itu perintah tersebut diiringi dengan menulis (Shihab, 2009: 33).Bahkan dalam masa turunnya wahyu,Rasul mempunyai sekretaris pribadi untuk menuliskan ayat yang telah diterima dari Jibril, yakni Zaid bin Tsabit.Ini landasan sejarah, menandakan betapa urgensnya tradisi menulis. Bahkan tulisanlah yang representatif dalam menggambarkan bagaimana pemikiran ilmuan masa lalu. Disaat alat teknologi belum mampu merekam segala hal yang dinginkan untuk disampaikan pada generasi masa depan. Tulisan menjadi salah satu cara tertua manusia dalam menyampaikan pesan, apa sesungguhnya yang terjadi pada masanya, dan pesan apa yang mau diutarakan sipenulis. Al-Quran pun memberikan isyarat yang lugas, dalam ayat muamalah, yang terdapat dalam surat al-Baqarah ayat 282, mengandung ajaran untuk menuliskan transaksi. Ini menjadi landasan kuat, betapa budaya tulis merupakan budaya sakral yang sudah ditetapkan oleh Allah dalam Islam. Tradisi menulis bukan saja dalam demensi kazanah intelektual tapi dalam aspek hubungan muamalah juga dianjurkan. 
Dengan demikian ada tiga doktrin utama, perintah menulis, pertama wahyu pertama turun, surah, al' alaq, kedua, Nabi memerintahkan wahyu kepada sahabatnya dan ketiga, perintah menuliskan transaksi dalam Al-Qur'an.

Dengan beberapa penjelasan diatas pemakalah memberikan atensi lebih pada motivasi para cendekiawan dalam menulis lebih kepada tanggung jawab sebagai seorang ilmuan. Tanggung jawab disini bukan hanya berhubungan antara manusia-dengan manusia tetapi juga antara dirinya dengan sang Khaliq. Beban yang diemban jauh lebih besar dibandingkan orang yang secara kualifikasi tidak mempunyai ilmu yang mumpuni. Disisi yang lain, ilmu tetap harus mengalir pada orang yang dikehendaki. Maka tidak ada cara yang lebih efektif bagi cendekiawan dalam menyampaikan pesan-pesan keilahian selain dengan tulisan. Kemudian secara dokrinal (Al-Qur'an dan Al-Hadis) Perintah untuk mengamalkan, bagian yang tidak terpisahkan dari prilaku cendekiawan. Aktivitas itu bisa berupa menciptakan sesuatu dengan penemuan atau karyakarya yang lumrah dimiliki oleh para intelektual, yang dikenal sebagai karya ilmiah seperti menulis.

Sudah sepantasnya intelektual Barat, mengakui kontribusi umat Islam dalam menyelamatkan peradaban sebelumnya, baik itu berasal dari Yunani, yang diterjemahkan oleh cendekiawan muslim dan memberikan tanggapan dan warna baru dengan pengayaan yang luar biasa. Ini dapat dinikmati oleh Eropa saat ini (Mendi, 2003 : 46). Ataupun ilmu baru yang dihasilkan oleh cendekiawan muslim. Doktrin di atas menjadi salah salah satu alasan utama karya tersebut dapat dititipkan kepada generasi selanjutnya, dari buku tersebut.

\section{B. Tradisi Menulis: Pasang Surut Faktor-Faktor Pendukung}

Menulis adalah bagian tradisi ilmiah dan ikonnya para cendekiawan. Dari menulis mereka dapat menyampaikan gagasan dan buah pikiran kepada orang lain. Namun tradisi menulis bagi cendekiawan tidaklah sama. Kebiasaan tersebut dan tinggi rendahnya hasil karya dari menulis dilatarbelakangi banyak faktor. Bahkan kualitas tulisan pun sangat tergantung oleh banyak faktor. Ada beberapa faktor yang turut memberikan andil tinggi rendahnya sebuah karya tulis, antara lain:

a. Sosial Politik

Kondisi sosial politik suatu bangsa memberikan efek yang yang cukup besar dalam melahirkan tulisan yang baik dan berkualitas dan secara kuantitas. Kalau dilihat dari hiruk pikuk sejarah perjalanan bangsa Indonesia, Negara ini pernah mengalami masa suram dalam kebebasan. Tertindas dalam aspek ekonomi, Pendidikan, militer, politik, sosial, budaya dan aspek yang lainnya. Hal itu sangat terasa pada zaman penjajahan. Imperialisme dan kolonialisme menjadi nama 


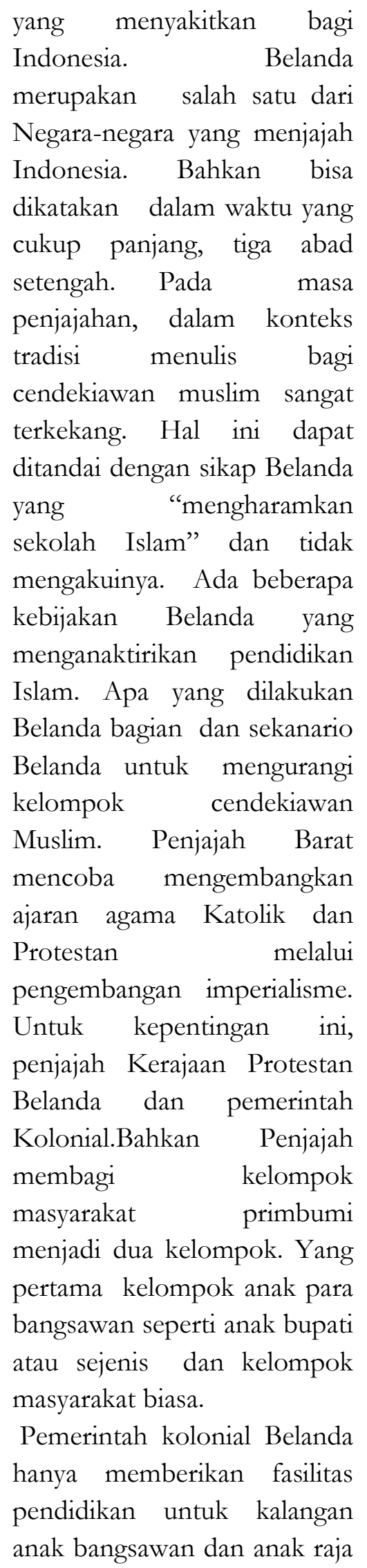

serta anak Eropa.Tidak lupa diberikan fasilitas. Sedangkan anak pribumi tersisihkan. Mereka tidak mendapatkan keadilan dalam mengenyam pendidikan. Di samping jumlah sekolah yang terbatas (Soedarmanta, 2006 : 214).Pesantren dijadikan target serangannya, ruthless operation (operasi yang tidak kenal belas kasih). Kiai atau ulamanya digantung. Bangunan dan sarana pendidikan lainnya dibakar atau dirusakkan. Santrisantrinya ditangkap dan dibuang jauh dari wilayah aslinya. Bahkan lembaga ini menjadi momok dari Belanda. karena dari kelompok inilah muncul para pejuang kemerdekaan dan disusul dengan organisasi keislaman.Politisasi

pengurusan pendidikan di zaman penjajahan membuat kreativitas penulisan ilmiah berjalan lambat. Porsi energi yang cukup besar dalam menghadapi penjajahan Belanda, turut memberikan andil lesunya tradisi menulis.

Secara sosial, Para cendekiawan muslim, dalam pandangan penulis, dikekang kreativitasnya, apalagi mereka membicarakan hal-hal yang berhubungan dengan kemerdekaan. Secara kemasyarakatan umat Islam mengalami penindasan yang 
cukup memprihatikan, penindasan ini masuk dalam segala aspek. Ekonomi, pendidikan apalagi keadilan (Abdurahman, 2006 : 80-81). Dari realitas tersebut para cendekiawan banyak mengaktualisasikan diriya berjuang melalui kelompok dan organisasi. Karena dengan membentuk kelompok dan ikatan akan lebih menguatkan perjuangan, sehingga secara tidak langsung mengurangi opsi dalam penulisan karya ilmiah. Dalam Demensi yang lain, Prilaku Belanda yang cendrung menangkapi para tokoh muslim dan ulama dan memonitor setiap perkembangan dimasyarakat menjadi alasan tersendiri. Karya ilmiah juga bisa menjadi alat propaganda dalam melancarkan ide-ide dan gagasan. Belanda sangat kwatir buah pikir cendekiawan muslim, memberikan semangat baru dan anti penjajah. Maka mengawasi para cendekiawan dalam setiap aktivitas merupakan alasan tersendiri bahwa menulis menjadi suatu pekerjaan yang berat. Karena para cendekiawan tidak bisa mengeluarkan ide-ide dan gagasan sesuai denga alam pikir dari penulis.

b. Waktu

Waktu juga berperan penting dalam melahirkan karya-karya berkualitas, secara tidak sadar diakui, bahwa para cendekiawan yang bergerak dalam organisasi pra kemerdekaan menyita waktu yang cukup besar, sehingga kesempatan dalam tradisi menulis menjadi terhambat atau kurang. Bahkan perlawanan kepada pejajajahan baik secara halus melalui badan dan organisasi ataupun mengangkat senjata landasan historis yang tak terbantahkan cukup memberikan andil dalam mengruangi eksistensi tulisan pada zaman pejajahan. Sistem tanam paksa dan kebijakan diskriminatif yang dibuat melanda memberikan efek yang cukup besar dalam tradisi menulis. Maksud pemakalah, menulis membutuhkan waktu yang tidak sedikit dan lingkungan yang mendukung untuk melahirkan karya besar, namuan situasi terjajah dan umat Islam selalu dibawa tekanan mempergaruhi ruang gerak dan daya nalar bagi para cendekiawan muslim di Indonesia.

c. Ekonomi

Menulis adalah pekerjaan yang tidak mendapatkan apresiasi yang baik, kalau ditinjau dalam pemberian fee bagi cendekiawan yang menulis. Yang paling pahit, adalah pada zaman penjajahan, disamping kegiatan dan aktivitas 
tersebut mendapat sorotan dan pengawalan ketat, hasil karya tidak mendapatkan tempat yang layak. Sehingga menulis, adalah pekerjaan menulis adalah sisa waktu yang masih tersedia. Tradisi ini bukan pekerjaan utama tapi lebih pekerjaan sampingan, bila memakai sudut pandang ekonomis, tidak ada pembayaran. Makanya para cendekiawan melakukan amal sholeh lebih dikarenakan landasan kepuasan batin dan panggilan murni seorang cendekiawan, bagaimana ide-ide yang ada dikepalanya dapat dibaca dan dilihat orang. Tanpa menharapkan balas jasa dari orang lain. Begitu juga hanya dengan perhatian pemrintah. Menulis bukan pekerjaan yang dapat membuat seseorang kaya. Bahkan aktivitas menulis bisa mengurangi porsi aktivitas yang lain. Kalau mengacu pada undang-undang guru dan dosen, kewajiban menulis baru muncul pada tahun 2005 untuk para dosen dan guru besar (Undang-undang Guru dan Dosen Pasal 49 ayat 2).Kewajiban tersebut diikuti dengan regulasi dalam kenaikan kepangkatan. Kurangnya insentif dan perhatian mempengruhi tradisi menulis sendiri (Azra, 1999 : 20). Namun jauh sebelum itu aktivitas menulis lebih dikarenakan kesadaran para cendekiawan untuk menjaga amanah dari umat Islam.

\section{Peta Khazanah Ilmiah Ilmuan Muslim Nusantara} Islam mengalami masa perkembangan ilmu pengetahuan mencapai kejayaan sekitar abad ke2/8 hingga abad ke -6/12 (Asari, 2005 : 229-241) tentu itu ditandai dengan tradisi ilmiah yang baik. Dimana Islam itu berada dan hadir dtengah masyarakat. Bahkan kejayaan suatu bangsa ditentukan sampai sejauh mana karya ilmiah dan ilmu pengetahuan benar-benar dapat perhatian yang layak. Begitu juga yang terjadi pada muslim di Nusantara, semenjak kehadiran Islam dan menjadi kekuatan politik mampu melahirkan kerajaan dan tradisi ilmiah.Tradisi ilmiah yang berkembang di wilayah Nusantara menjadi semakin nyata dengan adanya karya-karya yang dihasilkan oleh para ulama dan kaum intelektual lainnya, baik di bidang ilmu-ilmu keislaman maupun bidang lainnya. Dalam hal ini akan dipaparkan berbagai karya yang dihasilkan para ulama pada masa Kesultanan Islam Nusantara, terutama di wilayah Palembang, Aceh dan Riau.

Penulis menganalisis dari karya-karya yang dihasilkan para ulama dan cendekiawan muslim pada jaman kerajaan Islam diNusantara, lebih berorientasi kepada tema Fikih, 
Ibadah, Tasawuf dan Hadis, hikayat, tarikhdan lebih banyak bersifat terjemahan. Tidak dapat dipungkiri bahwa masuk dan menyebarnya Islam di Nusantara disaat Islam mengalami kemunduran Peradaban di Timur Tengah dan ini berpengaruh kepada penyebaran Islam dan corak karya yang dihasilkan. Sehingga tematemanya tidak berhubungan dengan ilmu pengetahuan secara lebih comprehensip dan melahirkan ilmuilmu baru. Hal ini dapat tergambar dari beberapa karya-karya cendekiawan kerajaan Islam di Nusantara, antara lain:

a. Di Kesultanan Palembang Darussalam

Berdasarkan karya-karya intelektual yang dihasilkan para penulis dan ulama Palembang, Hussni Rahim mengkategorikan mereka ke dalam tiga kelompok. Pertama, para penulis karyakarya dalam bidang ilmu-ilmu keislaman, seperti ilmu tauhid/kalam, tasawuf, tarekat, tarikh dan Al-Qur'an. Di antaranya adalah Syekh Syihabuddin bin Abdullah Muhammad yang menulis kitab Risala, 'Aqidat al-Bayan, dan menterjemahkan serta memberi syarah kitab Jawaharat al-Taubid karya Ibrahim Laqqani; Kemas Fakhruddin yang antara lain menulis kitab Mukhtashar, Futub al-Sha'am, Khawash AlQur'an, dan menterjemahkan kitab Tubfat al-Za'man fi Zharf Abl al-Yaman karya Ibn
Shaddad al-Himyari; Abdu Shamad al-Palimbani yang antara lain menulis kitab Zubrat al-Murid fi Bayan Kalimat al Taubid, Hidayat al-Salikin fi Suluk Maslak al-Muttaqin, Sair al-Salikin ila Ibadat Rabb al Alamin, Tubfat al-Raghibin fi Bayan Haqiqat Iman alMu'minin, Nasibat al-Muslimin wa Tazkirat al-Mu'minin fi Fadha'il al-jibad fi Sabil Allah wa Karamat al-Mujabidin fi Sabil Allah, dan kitab Ratib Abd Shamad al-Palimbani. Kedua, para penulis dalam bidang sastra. Di antaranya adalah Sultan Mahmud Badaruddin II yang menulis Syair Sinyor Kosta, Hikayat Martalaya, Sair Nuri, dan Pantun; Pangeran Panembahan Bupati yang menulis Syair Raja Mambang Jawhari, Syair Kembang Air Mawar, dan Syair Patut Delapan; dan Ahmad bin Abdullah yang menulis Hikayat Andaken Penurat. Ketiga, para penulis dalam bidang sejarah, yakni Pangeran Tumenggung Karta Menggala, yang menulis Cerita Negeri Palembang, Cerita daripada Aturan Raja-raja di dalam Negeri Palembang, dan Hikayat Mahmud Badaruddin; dan Demang Mubyiddin, seorang hakim pengadilan Palembang, yang menulis Silsilah Raja-raja di dalam Negeri Palembang. Beberapa karya tersebut merupakan sebagian dari karya yang dihasilkan ulama Palembang. Secara lebih 
lengkap dapat dilihat dalam Katalog Naskah Palembang, yang memuat tidak kurang dari 172 naskah dalam berbagai bidang. Sebagian besar karya-karya tersebut masih dalam bentuk naskah tulisan tangan yang tersimpan di berbagai tempat seperti Perpustakaan Nasional RI, Museum bala Putra Dewa, dan para pemilik yang bersifat perorangan.

b. Di Kesultanan Aceh

Pada masa Kesultanan Aceh wilayah ini merupakan salah satu pusat studi Islam di Nusantara. Pada masa inilah muncul para Ulama yang sangat produktif dalam menghasilkan karya-karya keislaman seperti Nuruddin al-Raniri, Abdur Rauf alSingkili (Nor Huda, 2015:140) Syamsuddin al Sumatrani dan lain-lain. Menurut Azyumardi, al-Raniri adalah penulis yang produktif dan terpelajar. Menurut berbagai sumber, dia menulis tidak kurang dari 29 karya, sementara Al-Sinkili menulis sekitar 22 karya yang membahas tentang fikih, tafsir, kalam dan tasawuf.

\section{c. Di Kesultanan Riau}

Tidak kalah dengan wilayah Aceh dan Palembang, daerah Kesultanan Riau juga banyak melahirkan ulama-ulama yang cukup produktif menghasilkan karya ilmiah. Di antara mereka yang cukup terkenal adalah Raja Ali Haji yang menulis karya antara lain Silsilah Melayu dan Bugis, Bustan alKa'tibin, Tuhfat al-Nafis, Gurindam Dua Belas, Syair Siti Syianah, Mukaddimah fi Intizam, dan Tsamarat alMuhimmah; Raja Ali Kelana yang menulis kitab tatabasa yang berjudul Rughyat al'Ani fi Huruf al-Ma'ni; Raja Abdullah yang menulis dua buah kitab pelajaran bahasa Melayu yang berjudul Pembuka Lidah dengan Teladan Umpama yang Mudah dan Penolong Bagi yang Menuntut Ilmu akan Pengetahuan yang Patut. Kegiatan ilmiah lainnya yang turut membantu perkembangan tradisi ilmiah ilmuwan Muslim adalah menyalin dan mendistribusikan karya ilmiah (buku). Fungsi penyalinan buku pada saat ini mungkin bisa disamakan dengan percetakan, tetapi pada masa pra-cetak, penyalinan buku telah memainkan peranan penting bagi penyediaan dan penyebarluasaan buku di seluruh wilayah kekuasaan Islam, termasuk wilayah Nusantara. Dalam hal ini tugas penyalinan buku-buku tersebut selain dilakukan oleh murid-murid si penulis buku, juga dilakukan seorang penyalin profesional yang 
disebut 'warraq". Profesi seorang "warraq" tentu bertambah penting ketika tuntutan terhadap buku semakin meningkat. Berkaitan dengan upaya penyebarluasan karya ilmiah, pada tahun 1885 di kerajaan Riau Lingga mendirikan sebuah percetakan yang dikenal dengan nama Rumah Cap Kerajaan. Percetakan inilah yang mencetak-yang ketika itu juga berarti menerbitkan- beberapa karya Raja Ali haji. Selain itu pada tahun 1894, Raja Muhammad Yusuf al-Ahmadi, dari Pulau Penyengat, juga mendirikan sebuah percetakan bernama Mathba'at alRiauwiyah atau Mathba'at alAhmadiyah. Percetakan ini sebenarnya juga merupakan lembaga penerbitan. Kitabkitab karya penulis Riau diberi cap Mathba'at al-Ahmadiyah, sedangkan tulisan-tulisan untuk kepentingan kerajaan diberi cap Mathba'at alRiauwiyah. Fakta di atas menunjukkan bahwa penerbitan buku telah merupakan sebuah tradisi penting dalam kerajaan Melayu. Munculnya dua penerbitan tersebut boleh dikatakan merupakan awal dari sejarah penerbitan buku di kawasan Nusantara. Di samping itu, dengan adanya percetakan tersebut maka khalayak pembaca karya-karya pengarang Melayu menjadi lebih luas dan tidak lagi terbatas di kawasan tempat tinggal orang melayu saja (Maryamah, 2016:8-9).

\section{Kebangkitan Tradisi}

Menulis Akhir Abad ke 20.

Abad Dua dupuluh ditandai dengan dua kebangkitan. Kebangkitan pertama munculnya gerakan pembaharuan dalam Islam. Kedua adalah perorangan, ditandai lahirnya para intelektual.

Ada beberapa nama Gerakan pembaharuan Islam pada abad ke 20 tersebut, diantaranya: Al-Jamiat $\mathrm{Al}$ Khair yang lebih dikenal dengan Jamiat kahir didirikan pada 17 Juli 1905 sebagai organisasi Islam tanpa diskriminasi asal-usul meskipun sebagian besar penggeraknya adalah Arab peranakan. Bidang usaha organisasi ini adalah pendidikan dan sosial. Untuk menyukseskan kegiatan usaha pendidikan, mereka memanggil pakar pendidikan, yaitu Syekh Ahmad Soorkati dari Sudan, Syekh Muhammad Thaib dari Maroko, dan Syaikh Muhammad Abdul Hamid dari Mekah. Di antara mereka, Ahmad Soorkati yang paling menonjol dalam hal menanamkan ide pembaharuan pendidikan dikalangan masyarakat Islam di Indonesia. Kehadiran tokoh pendidikan dari luar negeri yang semakin banyak pada umumnya adalah pengikut Muhammad Abduh. Mereka antara lain menganjurkan persamaan sesama muslim dan kembali ke pemikiran kepada AlQur'an dan Hadist. Sikap pemikiran ini ternyata mengundang reaksi keras, terutama dari peranakan Arab kelompok sayid yang selama ini 
menikmati penghormatan berlebihan dan merasa dirinya berkedudukan tinggi dari golongan lain dalam masyarakat Islam di Jawa. Perbedaan ini membawa organisasi Al-Khair mengalami perpecahan.Gerakan alIslah wal Irsyad atau al-Irsyad merupakan sempalan al-Khair karena terdapat perbedaan dalam jama'ah alKhair khususnya tentang persoalan "kafaah", yaitu boleh tidaknya golongan Arab keturunan Ali bin Abi Thalib(golongan Alawy) menikah dengan golongan lain. Menurut Soorkati, pernikahan seperti itu boleh berdasarkan surat al-Hujurat: 13 bahwa'yang dinilai paling mulia di sisi Allah adalah orang yang paling taqwa. Al Irsyad didirikan oleh Syekh Ahmad Soorkati pada 1914 dengan tujuan untuk memajukan pendidikan agama Islam secara murni di kalangan bangsa Arab peranakan. Untuk itu mereka mendirikan madrasah al-Irsyad, terutama di daerah pesisir, seperti Surabaya, Pekalongan, Tegal, dan Jakarta. Dalam bidang sosial dan dakwah Islam dengan dasar Al Qur'an dan As-Sunnah secara murni.Organisasi Persatuan Islam didirikan oleh $\mathrm{KH}$ Zamzam, ulama dari Palembang pada 17 September 1923 di Bandung. Tujuan Persis adalah mengembalikan kepemimpinan Islam pada Al-Qur'an dan hadist. Guna mewujudkan cita-cita tersebut, Persis melakukan berbagai usaha seperti mendirikan madrasah, pesantren, kegiatan tabligh, serta menerbitkan majalah dan buku agama. Majalah yang cukup populer dikalangan kaum muslimin di
Indonesia dan bahkan di mancanegara seperti Malaysia adalah majalah Pembela Islam dan AlMuslimun.Kiprah Persis dalam memerangi bid'ah dan khurafat yang disampaikan secara keras dan lugas memang sangat menonjol. Sikap semacam itu semakin menonjol di saat kepemimpinan ustadz A. Hasan, yang terkenal karena pena dan lidahnya yang tajam dalam menegakkan pemurnian agama. Popularitas A.Hasan saat memimpin Persis adalah korespondensiyang beliau lakukan dengan Bung Karno saat dibuang ke Endeh. Surat itu kemudian diterbitkan dalam bagian dari buku Bung Karno yang terkenal, yaitu Di Bawah Bendera Revolusi dalam bab Surat-surat Dari Endeh. Organisasi Muhammadiyah didirikan dikampung Kauman Yogyakarta pada 18 Novem-ber 1912. Sasaran dan wilayah gerak kegiatan Muhammadiyah seperti termaktub dalam anggaran dasar pertama adalah penduduk Jawa dan Madura. Kondisi objektif yg mendasari kelahiran Muhammadiyah adalah faktor internal yang terdiri dari ketidakmurnian amalan Islam sebagai akibat tidak dijadikannya Al Quran dan Sunnah Rasul sebagai satu-satunya rujukan oleh sebagian besar umat Islam Indonesia,lembaga pendidikan yang dimiliki umat Islam. Adapun organisasi Islam dan Politik diantara:Sarekat Islam, dengan masuknya Cokro-aminoto pada tahun 1912, mengalami kemajuan yang pesat berupa meluasnya dukungan bukan saja di seluruh Jawa, tetapi juga 
sampai ke Sumatra, Kalimantan, dan Sulawesi serta anggotanya mencakup berbagai lapisan masyarakat. Benda menyatakan bahwa SI mempunyai daya tarik yang jauh jangkauan-nya di luar penduduk kota yang berpendidikan Barat. Tujuh tahun setelah Cokroaminoto memimpin SI, partai ini memusatkan perhatiannya secara eksklusif pada orang Indonesia dengan merekrut semua kelas, baik di kota maupun di desa. Mereka adalah pedagang muslim, pekerja di kota, kyai dan ulama, beberapa priyayi, dan tak kurang pula petani ditarik dalam partai politik yang pertama di Indonesia dimasa kolonial ini. Masuknya paham sosialis membuat SI pecah menjadi SI merah dan SI Putih. Maka dari itu, pertentangan intern semakin tidak terkendali sehingga pada Kongres SI 1921 disiplin partai pun diterapkan dengan hasil keluarnya tokoh SI Merah, yaitu Semaun, Darsonodan Tan Malaka, yang kemudian mendirikan Partai Komunis Hindia. Kongres juga memutuskan untuk lebih menekankan identitas gerakan politik Islam dengan kalimat kemerdekaan yang berazaskan Islam. Yang sesungguhnya melepaskan segala rakyat dari penghambaan macam apapun juga. Pada Kongres tahun 1923, SI mengubah nama menjadi Partai Serikat Islam (Humaniora, 2007:153-154 Vol 19).

Secara personal, pembaharuan ditandai dengan hadirnya cendekiawan muslim yang banyak melahirkan karya tulis. Ada beberapa tokoh cendekiawan akhir abad 20 yang sangat dikenal dimasyarakat luas, antara lain: Abdul Malik Fadzar,
Abdurrahman Wahid, Taufik Abdullah, Quraish Syihab, Nurcholish Madjid (Nurcholis, 1987), AR Fahcruddin, Ahmad Syafii Maarif, Azyumardi Azra, dan masih banyak lagi yang tidak dapat penulis sebutkan. Menandakan ledakan intelektual terjadi pada akhir abad ke 20 luar biasa besarnya. Banyak faktor hal ini terjadi, diantaranya adalah dukungan sosial yang cukup besar, adanya kelompok intelektual yang tergabung dalam berbagai macam disiplin keilmuan, lahirnya Ikatan cendekiawan muslim Indonesia pada masa pemerintahan Soeharto, terlepas ada atau tidaknya kepentingan politik didalamnya. Pemerintah juga memberikan bantuan beasiswa kepada kelompok intelektual, bahkan karya tulis para intelektual sangat dimuliakan, yang penulis maksud adalah diberikan bentuk penghormatan dalam bentuk fee dan kemudahan mencetak karya tersebut. Teknologi juga bagian yang tidak dapat dipisahkan dari muncul arus tersebut. Segala informasi dan data begitu mudah diakses sehingga melancarkan para intelektual dalam melahirkan karyanya. Sekarang tergantung para inteletual sekarang dengan berbagai macam kemudahan tersebut dapat melahirkan karya-karya terbaik, sebagaimana dilahirkan para cendekiawan masa lalu, dengan segala keterbatasan informasi, tekhnologi dan dana.

\section{PENUTUP}

Seorang cendekiawan mempunyai naluri mulia untuk menyampaikan ide-idenya kepada orang lain. 
Proses itu bisa melalui lisan dan bisa juga melalui tulisan. Dalam konteks sejarah cendekiawan Muslim baik pada zaman kerajaan Islam di Nusantara dan sampai pada Abad ke 20 telah banyak melahirkan karya tulis dalam berbagai aspek. Meliputi hukum, ekonomi, sastra tafsir dan lainnya. Tokoh cendkiawan tidak hanya lahir dan berkembang dalam dunia Pesantren, tapi menyebar. Mereka juga ada di birokrasi, lembaga sosial kemasyarakatan.

Pasang surutnya hasil karya dari masing-masing tokoh, tidak lepas dari situasi yang melingkupi, baik politik, sosial budaya sampai penjajahan yang cukup lama. Pemerintah juga punya andil untuk berada diantara cendekiawan, mensuport mereka atau cendrung mengabaikannya. Namun bila dilihat dari konteks historis tulisan mereka lahir bukan karena ingin mendapatkan keuntungan secara ekonomi, tapi bagian yang tidak terpisahkan dalam tugas dan kewajiban mereka.

$$
\text { Pada abad ke-20, dengan }
$$

ditandai gerakan pembaharuan bermunculan para tokoh muslim dan melahirkan banyak karya ilmiah sebagai khazanah inteletual para cendekiawan muslim Indonesia. Para intelektual tersebut mempunyai andil yang cukup besar dalam memberikan kemerdekaan untuk rakyat Indonesia, mererka berjuang berdasarkan kapasitas mereka masing- masing.

\section{REFERENSI}

Azra, Azyumardi. 1999. Pendidikan Islam; Tradisi dan Modernisasi Menuju Milenium Baru. Jakarta: Logos Wacana Ilmu.

Asari, Hasan. 2007. Menyingkap Zaman Keemasan Islam. Bandung : Cita Pustaka.

Humaniora, Vol. 19, No. 2 Juni 2007. Huda, Nor. 2010. Sejarah Sosial Intelektual Islam Di Indonesia.Jakarta: Grafindo Persada.

Muhammad Alu Syaikh, Abdullah Bin. 2012.Tafsir Ibnu Katsir, terj. Abdul Ghoffar Abu Ihsan atsari, cet. V. Jakarta: Pustaka Imam Syafii.

Mas'ud, Abdurrahman. 2006. Dari Haramain Kenusantara. Jakarta: Kencana,Jaringan Ulama Timur Tengah dan Kepuluan Nusantara Abad XVII \& XVII, cet.2, Jakarta: Prenada.

Maryamah. 2016. “Tradisi Ilmiah

Dalam Peradaban Islam Melayu" dalam Tadrib Vol. II No. 2 Edisi Desember

Madjid, Nurcholisch. 1987. Islam Komodernan dan Keindonesiaan Bandung: Mizan.

Nasution, Harun. 2000.Islam Rasional, cet.VI. Bandung :Mizan.

Nakosteen, Mendi. 2003. Kontribusi Islam Atas Dunia Intelektual Barat; Diskripnasi Analisis Abad Keemasan Islam. Surabaya: Risalah Gusti.

Purwanto, Agus. 2008. Ayat- Ayat Semesta. Bandung: Mizan.

Soedarmanta, J.B. 2006. Jejak-Jejak Pablawan Nasional; Perekat 
Kesatuan Bangsa Indonesia. Jakarta: Grasindo.

Shihab, M. Quraisy. 2007. Secercah Cahaya Ilabi, cet. II. Bandung: Mizan.

-----. 2006. Jin, Iblis, Setan dan Malikat Yang Tersembunyi. Jakarta: Lentera Hati.

------. 2006. Wawasan Al-Qur'an, cet. XVII. Bandung: MIzan.

------, Tafsir Al-Misbah, cet. X. Jakarta: Lentera Hati, 2007.

------, Membumikan Al-Qur'an, cet. III. Bandung: Mizan, 2009.

Undang-Undang Republik Indonesia Pasal 49 ayat 2 nomor 14 Tahun 2005. 